YHCT điều tri đau thắt lưng do THCS[4],[6].Theo chúng tôi, với tác dụng điêu khí, giúp lưu thông khí huyết nơi kinh lạc bị bễ tắc, thúc đẩy quá trình sản sinh Endorphin nội sinh của điện châm kết hợp với tác dụng hoạt huyết hoá ứ, lý khí chỉ thống của bài thuốc Tứ vật đào hồng thang đã góp phần tạo nên hiệu quả điều trị tốt ở các $B N$ NNC cao hơn có ý nghĩa so với sử dụng điện châm đơn thuần.

\section{KẾT LUÂNN}

Bài thuốc Tứ vật đào hồng thang kết hợp điện châmhiệu quả tốt trong điều trị đau thắt lưng do thoái hóa cột sống:94,1\% đạt hiệu quả tốt và khá sau điều trị. VAS tăng từ $1,62 \pm$ 0,61 (điểm) trước điều trị lên còn $3,79 \pm 0,41$ (điểm) sau điều trị; độ giãn cột sống thắt lưng tăng từ $12,34 \pm 0,68(\mathrm{~cm})$ trước điều trị lên $14,23 \pm 0,52(\mathrm{~cm})$ sau điều trị. Tầm vận động cột sống thắt lưng trung bình các động tác tăng có ý nghĩa so với trước điêu trị.

\section{TÀI LIÊU THAM KHẢO}

1. Bộ Y tế (2020). Đau cột sống thắt lưng (Yêu thống). Hướng dẫn chẩn đoán và điêu trị bệnh theo y học cổ truyền, kết hợp y học cổ truyền với y học hiện đại, Nhà xuất bản Y học, Hà Nôi, 7-14.

2. Nguyến Đức Minh, Nguyễn Vinh Quốc (2018). Đánh giá tình trạng đau thắt lưng do thoái hóa cột sống trên bênh nhân điều tri tại Khoa Lão khoa, Bệnh viện Châm cứu Trung ương. Tạp chí Y dược lâm sàng $108,13(4), 87-92$.

3. Hồ Hữu Lương (2012). Đau thắt lưng và thoát vị đĩa đệm, Nhà xuất bản $Y$ hoc, Hà Nôi.

4. Trịnh Thị Hanh, Phạm Xuân Phong (2018) Điện châm kểt hợp thuốc Hoàn chỉ thông điêu trị thoái hóa côtt sống thắt lưng theo thể bênh $Y$ hoc cổ truyền. Tạp chí Y dược học cổ truyền Quân sự, 3(8), 46-53.

5. Lê Thị Kim Dung, Nguyễn Quang Dương, Đoàn Thị Nhung (2018). Nghiên cứu tác dụng giảm đau của bài thuốc TK1 kết hợp điên châm điều trị đau thắt lưng do thoái hóa cột sống thắt lưng. Tạp chí Y dược cổ truyền Việt Nam, 6(19), 31-38.

6. Pham Thị Ngọc Bích, Lê Thành Xuân (2016). Hiểu quả lâm sàng trong điều tri đau thắt lưng do thoái hóa côtt sống bằng điện trường châm kết hợp với bài thuốc độc hoat tang ký sinh. Tap chí nghiền cứu y học, 103(5), 32-39.

7. 周慎 và '何清湖 (2004). 止痛本草, 中医古籍出版社，北京.

8. Bộ môn $\mathbf{Y}$ học cố truyên - Trường đại học $Y$ Hà Nô̂i (2005). Châm cứu, NXB Y họ, Hà Nội.

\title{
KẾT QUẢ ĐIỀU TRI PHẪU THUÂTT VIÊM MÀNG NGOÀI TIM CO THẮT TẠI BỆNH VIỆN HỮU NGHI VIỆT ĐỨC
}

\section{Bùi Thanh Hùng ${ }^{2}$, Đoàn Quốc Hưng ${ }^{1,2}$, Đinh Văn Lượng ${ }^{3}$}

\section{TÓM TẮT}

Mục tiêu: Mô tả đặc điểm lâm sàng, cận lâm sàng của viềm màng ngoài tim co thắt và nhận xét kết quả phẫu thuật viêm màng ngoài tim co thắt tại bệnh viện Hữu nghị Việt Đức. Đối tượng và phương pháp: Nghiên cứu hồi cứu mô tả nhữ̛̃ng bênh nhân viêm màng ngoài tim co thắt được phẩu thuật tại trung tâm Tim mạch và lồng ngực Bệnh viện Hữu Nghị Việt Đức từ tháng 1/2014 đến tháng 12/2020. Kết quả: Có 14 bệnh nhân, trong đó 9 bệnh nhân nam $(64,3 \%)$. Độ tuổi trung bình là $47 \pm 19,8$. Nguyên nhân bênh là lao gặp ở 6 bệnh nhân $(42,9 \%)$, còn 8 bệnh nhẩn là viêm không đăc hiêu (57,1 \%). Tất cả bênh nhân đều được phẫu thuật cắt màng ngoài tim rộng rãi với đường mổ giữa xương ức. Thời gian mổ trung bình $175 \pm 31,3$ phút. Không có tử vong sau mổ và $100 \%$ có tình trạng

\footnotetext{
${ }^{1}$ Bệnh viện Hữu Nghị Việt Đức,

¿Đại học Y Hà Nôi,

${ }^{3}$ Bệnh viện Phổi Trung ương

Chịu trách nhiệm chính: Đoàn Quốc Hưng,

Email: hung.doanquoc@gmail.com.

Ngày nhận bài: 9/7/2021

Ngày phản biên khoa họ: 28/7/2021

Ngày duyệt bài: 24/8/2021
}

khó thở giảm đi ít nhất một bậc theo phân độ của hiệp hội Tim mạch New York (NYHA). Kết luận: Viêm màng ngoài tim co thắt là một bênh không thường gặp gây nên bởi sự dày dính và vôi hóa màng ngoài tim. Phẫu thuật cắt màng tim rộng rãi mang lại hiệu quả điều trị cao và an toàn.

Tứ khóa: Viêm màng ngoài tim, co thắt, phẫu thuật cắt màng tim, lao, viêm màng ngoài tim dày dính.

\section{SUMMARY}

RESULTS OF PERICARDECTOMY FOR

CONSTRICTIVE PERICARDITIS AT VIET DUC UNIVERSITY HOSPITAL

Objectives: To describe clinical and subclinical presentations of constrictive pericarditis and access results of pericardectomy for constrictive pericarditis at Viet Duc university hospital. Material and method: This is a retrospective, descriptive study of patients who underwent pericardiectomy for constrictive pericarditis at Cardiovascular and Thoracic center, Viet Duc University Hospital from 1/2014 to 12/2020. Result: There were 14 patients in total, nine were male $(64,3 \%)$. The mean age was $47 \pm 19,8$. Etiology of constrictive pericarditis was tuberculosis in 6 patients $(42,9 \%)$ and idiopathic for the remains $(57,1 \%)$. Extensive pericardectomy was performed in all patients with median sternotomy. The mean 
operative time was $175 \pm 31,3$ min. There was no inhospital mortality and all of patients improved at least one New York Heart Association (NYHA) functional class after surgery. Conclusion: Constrictive pericarditis is a rare disease that can result in chronic fibrous thickening of the pericardium. The use of pericardectomy for constrictive pericarditis was effective and safe.

Keyword:

Pericarditis,

constrictive, pericardectomy, tuberculous, adhesive pericarditis.

\section{I. ĐẶT VẤN ĐỀ}

Viêm màng ngoài tim co thắt đã được đề cập đến cách đây nhiều thế kỉ. Bệnh biểu hiện chủ yếu bởi sự chèn ép tim phải mà nguyên nhân là do sự xơ hóa, dày lên của màng ngoài tim. Đây là một bệnh không thường gặp. Mặc dù đã được đề cập đến từ lâu nhưng cơ chế bệnh sinh của viêm màng ngoài tim co thắt vẫn được cho là rất phức tạp, với nhiều yếu tố liên quan. Các triệu chứng lâm sàng và cận lâm sàng đôi khi không rõ ràng đặc biệt là giai đoạn sớm của bệnh. Phẫu thuật cắt màng tim rộng rãi được xem như là phương pháp điều trị chính. Tại Việt Đức, chúng tôi đã có kinh nghiệm nhiêu năm thực hiện phẫu thuật này. Vì vậy, chúng tôi làm nghiên cứu này nhằm mô tả đặc điểm lâm sàng, cận lâm sàng và nhận xét kết quả điều trị phẫu thuật viêm màng ngoài tim co thắt.

\section{II. ĐỐI TƯƠNGG VÀ PHƯƠNG PHÁP NGHIÊN CỨU}

Nghiên cứu hồi cứu mô tả những bệnh nhân viêm màng ngoài tim co thắt được phẫu thuật tại Trung tâm tim mạch và lồng ngực Bệnh viện Hữu Nghị Việt Đức từ tháng 1/2014 đến tháng 12/2020.

\section{KẾT QUẢ NGHIÊN CỨU}

Có 14 bệnh nhân trong đó có 9 nam $(64,3 \%)$

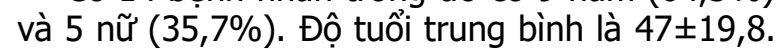
Các lý do vào viện gồm có: Khó thở (100\%), đau ngực $(64,3 \%)$, ho $(14,3 \%)$, cổ chướng $(7,1 \%)$, phù hai chân $(7,1 \%)$ và phù toàn thân $(7,1 \%)$.

Bảng 1. Triệu chứng lâm sàng $(N=14)$

\begin{tabular}{|c|c|c|}
\hline Triệu chứng lâm sàng & $\mathbf{N}$ & Tỷ lệ (\%) \\
\hline Khó thở & 14 & 100 \\
\hline Đau ngực & 7 & 50 \\
\hline Gan to & 9 & 64,3 \\
\hline Phù chi dưới & 5 & 35,7 \\
\hline Cố trướng & 4 & 28,6 \\
\hline Tĩnh mạch cố nối & 4 & 28,6 \\
\hline Ho & 2 & 14,3 \\
\hline
\end{tabular}

Bảng 2. Triệu chứng cận lâm sàng (N=14)

\begin{tabular}{|c|c|c|c|}
\hline \multirow{2}{*}{ Xquang } & Hình ảnh & $\mathbf{N}$ & $\begin{array}{c}\text { Tỳ lề } \\
(\mathbf{\%})\end{array}$ \\
\cline { 2 - 4 } & Vôi hóa màng tim & 5 & 35,7 \\
\hline & Bóng tim to & 10 & 71,4 \\
\hline
\end{tabular}

\begin{tabular}{|c|c|c|c|c|}
\hline & \multicolumn{2}{|c|}{ Chỉ số tim ngực } & \multicolumn{2}{|c|}{$55,5 \pm 7,5$} \\
\hline \multirow{8}{*}{$\begin{array}{l}\text { Siêu âm } \\
\text { tim }\end{array}$} & \multicolumn{2}{|c|}{ Tràn dịch màng tim } & 9 & 64,3 \\
\hline & \multicolumn{2}{|c|}{ Chèn ép thất phải } & 3 & 21,4 \\
\hline & \multicolumn{2}{|c|}{ Dày màng tim } & 14 & 100 \\
\hline & \multicolumn{2}{|c|}{ Vôi hóa màng tim } & 11 & 78,6 \\
\hline & \multirow{4}{*}{$\begin{array}{c}\text { Áp lực } \\
\text { động } \\
\text { mạch phổi }\end{array}$} & Tăng cao & 1 & 7,1 \\
\hline & & Tăng vừa & 6 & 42,9 \\
\hline & & Tăng nhẹ & 5 & 35,7 \\
\hline & & Không tăng & 2 & 14,3 \\
\hline \multirow{2}{*}{$\begin{array}{l}\text { Cắt lớp vi } \\
\text { tính }\end{array}$} & \multicolumn{2}{|c|}{ Dày màng tim } & 14 & 100 \\
\hline & \multicolumn{2}{|c|}{ Tràn dịch màng tim } & 7 & 50 \\
\hline
\end{tabular}

Trong mổ, không có bệnh nhân nào phải sử dụng tuân hoàn ngoài cơ thể (CPB). Thời gian mổ trung bình là $175 \pm 31,3$ phút, trong đó ngắn nhất là 120 phút, dài nhất là 230 phút. Tất cả bệnh nhân được phẫu thuật cắt màng tim rộng rãi với đường mổ giữa xương ức.

Bảng 3. Một số chi số trong và sau mổ $(N=14)$

\begin{tabular}{|c|c|c|}
\hline Chỉ số nghiên cứu & $\begin{array}{c}\text { Số bệnh } \\
\text { nhẩn }\end{array}$ & $\begin{array}{c}\text { Tỉ lệ } \\
\text { (\%) }\end{array}$ \\
\hline Viêm phối & 1 & 7,1 \\
\hline Suy thận & 1 & 7,1 \\
\hline Suy đa tạng & 0 & 0 \\
\hline Đột quy. & 0 & 0 \\
\hline Ngưnng tuâan hoàn & 0 & 0 \\
\hline Nhiếm khuấn huyết & 0 & 0 \\
\hline Chảy máu trong mố phải \\
truyền máu
\end{tabular}

Bảng 4. Mức độ NYHA trước và sau mổ $(N=14)$

\begin{tabular}{|c|c|c|c|c|c|}
\hline \multirow{2}{*}{ NYHA } & \multicolumn{2}{|c|}{ Trước mố } & \multicolumn{2}{c|}{ Sau mố } & \multirow{2}{*}{ p } \\
\cline { 2 - 5 } & $\mathbf{n}$ & $\mathbf{0}$ & $\mathbf{n}$ & $\mathbf{\%}$ & \\
\hline I & 0 & 0 & 10 & 71,4 & \multirow{2}{*}{0,} \\
\hline II & 2 & 57,1 & 4 & 28,6 & 0 \\
\hline III & 3 & 28,6 & 0 & 0 & 1 \\
\hline IV & 4 & 14,3 & 0 & 0 & \\
\hline
\end{tabular}

Sử dụng so sánh ghép cặp đánh giá sự tương quan mức độ khó thở của bệnh nhân trước và sau mổ thây sự khác biệt có ý nghĩa thống kê $(p=0,001)$. Tỷ lệ bệnh nhân có NYHA III-IV trước mổ chiếm $42,9 \%$ giảm xuống còn $0 \%$ sau mổ, tỷ lệ bệnh nhân không khó thở hoặc khó thở nhẹ sau mổ tăng lên 100\%. 
Bảng 5. Các chỉ số siêu âm tim và áp lực tĩnh mạch trung tâm trước và sau mố

\begin{tabular}{|c|c|c|c|}
\hline $\begin{array}{c}\text { Chỉ số nghiên } \\
\text { cứu }\end{array}$ & Trước mổ & Sau mổ & $\mathbf{p}$ \\
\hline EF & $62,3 \pm 6,8$ & $67,7 \pm 7,0$ & 0,032 \\
\hline $\begin{array}{c}\text { Dường kính thất } \\
\text { phải }\end{array}$ & $19,1 \pm 2,4$ & $20,2 \pm 6,0$ & 0,203 \\
\hline $\begin{array}{c}\text { Ap lực động } \\
\text { mạch phổi } \\
\text { (mmHg) }\end{array}$ & $34,8 \pm 10,6$ & $26,3 \pm 6,4$ & 0,001 \\
\hline $\begin{array}{c}\text { Ap lực tĩnh mạch } \\
\text { trung tâm CVPP } \\
\text { (cmH } 20)\end{array}$ & $19,2 \pm 4,1$ & $14,4 \pm 2,4$ & 0,000 \\
\hline
\end{tabular}

Kết quả siêu âm tim sau mố cho thây phân suất tống máu thất trái tăng có ý nghĩa thống kê từ $62,3 \pm 6,8 \%$ lên $67,7 \pm 7,0 \%(p=0,032)$ và áp lực động mạch phổi giảm có ý nghĩa thống kê từ $34,8 \pm 10,6 \mathrm{mmHg} x$ xuống $26,3 \pm 6,4 \mathrm{mmHg}$. Nhưng đường kính thất phải lại thay đổi không có ý nghĩa thống kê $(p=0,203)$. CVP trước mổ và sau mổ khác biệt có ý nghĩa thống kê $(p=0,000)$, giảm từ $19,2 \pm 4,1 \mathrm{cmH}_{2} 0$ xuống $14,4 \pm 2,4 \mathrm{cmH}_{2} 0$.

\section{BÀN LUẬN}

Có 14 bệnh nhân đủ tiêu chuẩn nghiên cứu. Lý do vào viện chủ yếu là khó thở $(100 \%)$ và đau ngực $(64,3 \%)$. Tỷ lệ này cao hơn so với nghiên cứu của Murat Bicer trên 47 bệnh nhân là $72,3 \%$ khó thở và $21,3 \%$ đau ngực ${ }^{1}$. Trên lâm sàng, triệu chứng nổi bật là triệu chứng suy tim phải, gồm: Gan to $(64,3 \%)$, phù chi dưới $(35,7 \%)$, tĩnh mạch cổ nổi $(28,6 \%)$, và cổ chướng $(28,6 \%)$ (Bảng 1). Trong đó, tỷ lệ gan to và cổ chướng cao hơn so với nghiên cứu của Murat Bicer $(23,4 \%$ và $19,1 \%)$, tỷ lệ phù chi dưới và tĩnh mạch cổ nổi thấp hơn (42,5\% và $34 \%)^{1}$.

Trên siêu âm tim, các hình ảnh hay gặp là dày màng tim $(100 \%)$ và vôi hóa màng tim $(78,6 \%)$. Trên Xquang ngực, các hình ảnh hay gặp là bóng tim to $(71,4 \%)$ và vôi hóa màng tim $(35,7 \%)$ (Bảng 2). Tỷ lệ bóng tim to trên Xquang cao hơn so với nghiên cứu của Anurag Mehta $(37 \%)^{3}$. Điều này là do trong nghiên cứu của chúng tôi, viêm màng ngoài tim co thắt thường đi kèm với tràn dịch màng tim (64,3\%) (Bảng 2), làm bóng tim to lên thay vì bình thường hoặc nhỏ lại như viêm màng ngoài tim co thắt thông thường ${ }^{3,6}$.

Về điêu trị, bệnh viện Việt Đức đã có nhiều kinh nghiệm trong phấu thuật viêm màng ngoài tim co thắt. Chúng tôi có sự chuẩn bị bệnh nhân kĩ càng trước mổ như: Đặt đường truyền cả chi trên và chi dưới, chuẩn bị sẵn dụng cụ để chạy tuần hoàn ngoài cơ thể và kim chỉ mạch máu, vật liệu cầm máu (bông surgicel, keo sinh học), máu truyền. Trong mổ, chúng tôi sử dụng đường mổ rộng rãi là đường giữa xương ức: Tất cả bệnh nhân trong nghiên cứu của chúng tôi đều sử dụng đường mổ này. Việc bóc màng tim được tiến hành tỉ mỉ và cẩn thân, đặc biệt ở vi trí các động mạch vành, bóc từ chố dễ đến chố khó, hạn chế đè ép tim lúc bóc mặt sau tim, ưu tiên bóc tối đa lỗ đổ vào của tĩnh mạch chủ trên và chủ dưới, giải phóng tối đa thất phải, tuy nhiên cũng không cố lấy hết mảng vôi hóa vì nguy cơ gây rách cơ tim, thủng buồng tim. Trong trường hợp rách cơ tim, chúng tôi sử dụng chỉ mạch máu có miếng đềm để khâu. Miếng đệm có thể là vật liệu tổng hợp hoặc làm từ màng ngoài tim của chính bệnh nhân. Thời gian phẫu thuật trung bình là $175 \pm 31,3$ phút. Thời gian này dài hơn so với nghiên cứu của $B$. Cinar (140 \pm 70 phút) và nghiên cứu của Murat Bicer (156,4 445,7 phút), nhưng thấp hơn so với nghiên cứu của Yoshiyuki Tokuda trên 346 bênh nhân là $265 \pm 105$ phút $t^{1,2,5}$.

Biến chứng phấu thuât trong nghiên cứu của chúng tôi gồm có: Suy thận $(7,1 \%)$ và viêm phổi $(7,1 \%)$ (Bảng 3). Tỷ lệ suy thận thấp hơn so với nghiên cứu của Yoshiyuki Tokuda $(9,8 \%)$. Tỷ lệ viêm phổi cao hơn so với nghiên cứu của Yoshiyuki Tokuda $(4,6 \%)$. Ngoài ra tác giả Yoshiyuki Tokuda còn nhắc đến các biến chứng khác không xảy ra trong nghiên cứu của chúng tôi như: Suy đa tạng, đột qụy, ngừng tuần hoàn, rung nhĩ... $50 \%$ bệnh nhân phải dùng thuốc trợ tim sau mổ do hội chứng cung lượng tim thấp, cao hơn so với nghiên cứu của Murat Bicer $(23,4 \%)^{1}$. Bênh nhân sau mổ có áp lực tĩnh mạch trung tâm và áp lực động mạch phổi giảm, cải thiện được tình trạng khó thở ít nhất một bậc theo phân độ NYHA, sự thay đổi có ý nghĩa thống kê (Bảng 4,5). Không có bênh nhân tử vong sớm sau mố. So sánh với một số nghiên cứu khác trên thế giới, tỷ lệ tử vong sớm sau mổ là: Murat Bicer $(2,1 \%)$, B. Cinar $(8,6 \%)$, Yoshiyuki Tokuda $(10 \%)$ và Ana M. Peset $(16 \%)$. Như vậy kết quả sớm của phẫu thuật là tương đối tốt.

Nghiên cứu của chúng tôi thấy nguyên nhân bênh lao chiếm tỷ lệ lớn (42,9\%). Kết quả này cũng tương tự như nghiên cứu của Murat Bicer và cộng sự nẳm $2015(46,8 \%)^{1}$. Ngoài ra Murat Bicer và cộng sự cũng chỉ ra các nguyên nhân khác như vô căn, ung thư, sau xạ trị, sau phẫu thuật tim nhưng không thấy ở nghiên cứu của chúng tôi. Điều này có thể lý giải do số lượng bênh nhân trong nghiên cứu của chúng tôi còn hạn chế, ngoài ra các bệnh nhân chỉ được làm giải phẫu bệnh với mục đích là tìm nguyên nhân do lao để điều trị thuốc lao sau phẫu thuật, nên 
chưa tầm soát được các nguyên nhân khác.

\section{KẾT LUẦN}

Viêm màng ngoài tim co thắt có đặc điểm lâm sàng nổi bật là triệu chứng của suy tim phải. Siêu âm tim và cắt lớp vi tính đóng một vai trò quan trọng trong việc khẳng định chẩn đoán. Phẫu thuật cắt màng tim rộng rãi đem lại kết quả sớm sau mổ tương đối tốt.

\section{TÀI LIỆU THAM KHẢO}

1. Murat Bicer, Bulent Ozdemir, Iris Kan, et al. Long-term outcomes of pericardiectomy for constrictive pericarditis. Journal of cardiothorac surgery.2015;10:177.

2. B. Cinar, Y. Enc, O. Gokse, et al. Chronic constrictive tuberculous pericarditis: Risk factors and outcome of pericardiectomy. Int J Tuberc Lung Dis.2006;10(6):701-6.

3. Anurag Mehta, Mahaveer Mehta, Abnash $C$. Jan, et al. Constrictive Pericarditis. Clin Cardiol.1999;22(5):334-344.

4. Ana M. Peset, Vicens Marti, Montserrat Cardona, et al. Outcome of Pericardiectomy for Chronic Constrictive Pericarditis. Rev Esp Cardiol. 2007;60(10):1097-101.

5. Yoshiyuki Tokuda, Hiroaki Miyata, Noboru Motomura, et al. Outcome of Pericardiectomy for Constrictive Pericarditis in Japan: A Nationwide Outcome Study. Ann Thorac Surg.2013;96(2):571-6.

6. Adler $Y$, Charron $P$, Imazio $M$, et al. ESC Guidelines for the Diagnosis and Management of Pericardial Diseases. Task Force for the Diagnosis and Management of Pericardial Diseases of the European Society of Cardiology. G Ital Cardiol (Rome).2015;16(12):702-38.

\section{ĐĂC ĐIỂM MÔ BỆNH HỌC CỦA BÊ̂NH GAN DO RƯợU}

\section{TÓM TẮT}

Mục tiêu: Xác định đặc điểm mô bệnh học của bệnh gan do rượu. Đối tượng và phương phá: Gồm 60 bệnh nhân mắc bệnh gan do rượu điều trị nội trú tại Bệnh viện Quân y 103, từ tháng 01/2015 đến 7/2017. Các chỉ số nghiên cứu là hình thái gan nhiễm mõ và giai đoan xơ hóa gan theo Metavir, gồm: F0 (không xơ hóa), F1 (xơ hóa nhẹ); F2 (xơ hóa vửa), F3 (xơ hóa nặng) và $F 4$ ( $x o ̛$ gan thực sự). Kết quả và kết luận: $100 \%$ bệnh nhân mắc bệnh gan do rượu có gan nhiễm mỡ. Phần lớn là nhiễm mỡ giot nhỏ $(71,7 \%)$, mức độ nhẹ $(93,3 \%)$ và ở vùng 1 (90,0\%). Một số tổn thương khác hay gặp là thoái hóa hạt $(100 \%)$, thể Mallory $(65,0 \%)$, nhiếm sắc tố $(28,3 \%)$ và biến đổi ưa toan tế bào gan (15,0\%). Đánh giá giai đoạn xơ hóa gan theo phân loại Metavir thấy không xơ hóa gan (F0) là $6,7 \%$; xơ hóa nhe ( $F 1$ ) là $50,0 \%$; xơ hóa gan vừa (F2) là 11,7\%; xơ hóa gan nặng (F3) là $15,0 \%$ và xơ gan thực sự (F4) là 16,7\%.

Tư khóa: Bệnh gan do rượu, mô bệnh học, xơ hóa gan, xơ gan.

\section{SUMMARY \\ HISTOPATHOLOGICAL CHARACTERISTICS OF ALCOHOLIC LIVER DISEASE}

Objective: To determine the histopathological characteristics of alcoholic liver disease. Subjects and methods: 60 patients with alcoholic liver disease were inpatient at 103 Military Hospital, from January 2015 to July 2017. The research indicators are fatty liver morphology and liver fibrosis stage according to

*Học viện Quân y

Chịu trách nhiệm chính: Seng Someth

Email: nguyenvankhoi1980@gmail.com

Ngày nhận bài: 30/6/2021

Ngày phản biên khoa học: 31/7/2021

Ngày duyệt bài: 23/8/2021

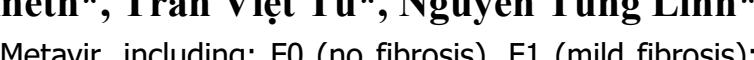
F2 (moderate fibrosis), F3 (severe fibrosis) and F4 (cirrhosis). Results and conclusion: $100 \%$ of patients with alcoholic liver disease had fatty liver. The majority were fatty dropsy (71.7\%), mild (93.3\%), and in zone 1 (90.0\%). Some other common lesions are foamy degeneration $(100 \%)$, Mallory body $(65.0 \%)$, chromophore $(28.3 \%)$ and hepatocellular eosinophilia (15.0\%). Evaluation of liver fibrosis stage according to Metavir classification showed no liver fibrosis (F0) was $6.7 \%$; mild fibrosis (F1) was $50.0 \%$; moderate liver fibrosis (F2) was $11.7 \%$; Severe cirrhosis (F3) was $15.0 \%$ and cirrhosis (F4) was $16.7 \%$.

Keywords: Alcoholic liver disease, histopathology, liver fibrosis, liver cirrhosis.

\section{I. ĐẶT VẤN ĐỀ}

Mô bệnh học là tiêu chuẩn vàng để đánh giá mức độ viêm, hoại tử nhằm tiên lượng, theo dõi điều trị bệnh gan do rượu (BGDR). Khoảng $90 \%$ số người nghiện rượu có gan thoái hóa mõ (GTHM), lúc đầu là vùng 3 , nếu tiếp tục uống rượu tình trạng thoái hóa mõ sẽ nặng, lan tỏa toà̀n gan. Nhiễm mõ gan dưới ba dạng: giọt nhỏ, giọt lớn và hỗn hợp. Trong BGDR, nhiềm mõ gan giọt lớn hay gặp hơn [1], [2], [3].

Thoái hóa hạt do rượu thường gặp ở GTHM do rượu: tế bào gan phồng lên với các hạt trong bào tương phân tán thành các sợi mảnh. Nhân tế bào nhỏ và bắt màu đậm (tăng sắc). Rượu làm tổn thương màng ty thể và làm ty thể phồng to, tạo nên các thể hình cầu trong bào tương. Bên trong những tế bào gan thường thấy các thể Mallory do sự ngưng tập các protein nội bào [4], [5], [6], [7]. Đặc điểm đại thể gợi ý xơ gan do rượu bao gồm khối lượng thùy đuôi lớn hơn, 